\title{
KOMPETENSI SUMBER DAYA MANUSIA DALAM PENYELENGGARAAN HEMODIALISIS DI RUMAH SAKIT DIHUBUNGKAN DENGAN ASAS PERLINDUNGAN HUKUM
}

Penelitian Hukum Normatif Terhadap Undang-Undang Nomor 44 Tahun 2009 Tentang Rumah Sakit Dan Permenkes No. 812 Tahun 2010 tentang Penyelenggaraan Pelayanan Dialisis pada Fasilitas Pelayanan Kesehatan

\author{
Irene Ranny Kristya Nugraha, P. Lindawaty S. Sewu dan Tammy J. Siarif \\ irene ranny@gmail.com \\ Magister Hukum Kesehatan \\ Universitas Katolik Soegijapranata Semarang
}

\begin{abstract}
ABSTRAK
Di Indonesia jumlah pasien yang menderita penyakit gagal ginjal yang membutuhkan terapi hemodialisis setiap tahunnya makin meningkat. Namun peningkatan ini tidak seimbang dengan jumlah sumber daya manusia yang berkompeten dalam bidang hemodialisis, terutama dokter spesialis penyakit dalam konsulen ginjal hipertensi dan dokter spesialis penyakit dalam terlatih bersertifikat pelatihan dialisis. Ketidakseimbangan ini dapat diatasi dengan memberikan pelimpahan kewenangan dan diberikan suatu kewenangan klinis (clinical privilege) kepada dokter umum yang terlatih bersertifikat hemodialisis yang bekerja di unit hemodialisis di Rumah Sakit sebagai dokter pelaksana.

Penelitian yang dilakukan adalah penelitian deskriptif analisis dengan pendekatan yuridis normatif, dimana diberikan gambaran/deskripsi peraturan perundang-undangan yang berlaku, dalam hal ini Peraturan Menteri Kesehatan Republik Indonesia Nomor 812 Tahun 2010 tentang Penyelenggaraan Dialisis Pada Fasilitas Pelayanan Kesehatan dikaitkan dengan asas perlindungan hukum. Data yang digunakan adalah data sekunder dengan teknik pengumpulan berupa studi pustaka.

Berdasarkan penelitian yang telah penulis lakukan, diketahui bahwa ketentuan tentang penyelenggaraan pelayanan dialisis berdasarkan Peraturan Menteri Kesehatan Republik Indonesia Nomor 812 Tahun 2010 tentang Penyelenggaraan Pelayanan Dialisis pada Fasilitas Pelayanan Kesehatan telah memenuhi asas perlindungan hukum.

Kata kunci : sumber daya manusia, hemodialisis, kompetensi, kewenangan klinis, rumah sakit, perlindungan hukum.
\end{abstract}




\section{PENDAHULUAN}

\section{Latar Belakang}

Pembangunan kesehatan dilaksanakan oleh semua komponen bangsa yang bertujuan untuk meningkatkan kesadaran, kemauan, dan kemampuan hidup sehat bagi setiap individu maupun masyarakat agar dapat mewujudkan peningkatan derajat kesehatan masyarakat yang setinggi-tingginya.

Semakin berkembangnya jaman dan akal budi manusia maka semakin berkembangnya pula ilmu pengetahuan dan teknologi. Perkembangan dalam bidang medis berkaitan dengan semakin berkembangnya ilmu pengetahuan mengenai jenis-jenis penyakit. Perkembangan ilmu pengetahuan dan teknologi ini berjalan seiringan dengan meningkatnya pemikiran manusia untuk menemukan terapi yang terbaik untuk mengobati suatu jenis penyakit.

Penyakit ginjal kronik (PGK) merupakan salah satu jenis penyakit degeneratif dengan prevalensi terbesar di dunia. Pada PGK terjadi gangguan struktur atau fungsi ginjal lebih dari 3 bulan, dimana terjadi penurunan fungsi ginjal yang pada suatu saat akan mencapai tahap penurunan tertentu yang tidak dapat dihindari lagi dan sering bermanifestasi tanpa gejala sehingga dapat berkembang ke tahap lanjut menjadi penyakit ginjal tahap akhir (disebut juga gagal ginjal kronis atau end stage renal disease). Dengan terdiagnosisnya suatu penyakit sebagai penyakit gagal ginjal kronis maka dibutuhkan suatu terapi pengganti ginjal.

Terapi yang diperlukan untuk mengobati penderita dengan penyakit gagal ginjal kronik adalah melalui terapi pengganti ginjal, dimana salah satunya melalui cara dialisis. Di Indonesia sendiri, hemodialisis masih merupakan pilihan utama terapi pengganti ginjal dalam penatalaksanaan penyakit Gagal Ginjal Terminal/End Stage Renal Disease.

Di Indonesia angka kejadian penderita dengan diagnosis Gagal Ginjal Terminal/End Stage Renal Disease yang menjalani terapi hemodialisis setiap tahunnya makin meningkat. Data yang diperoleh dari $3^{\text {th }}$ Report Of Indonesian Renal Registry (IRR) jumlah pasien baru penyakit gagal ginjal yang harus menjalani terapi hemodialisis pada tahun 2010 sebanyak 9649 pasien baru penyakit gagal ginjal yang harus menjalani terapi hemodialisis. Dari jumlah tersebut, 83\% merupakan pasien Gagal Ginjal Terminal/End Stage Renal Disease, dimana pasien ini harus menjalani terapi hemodialisis secara rutin. ${ }^{1}$

Dikarenakan pada setiap tahunnya angka kejadian penyakit gagal ginjal kronis yang membutuhkan terapi pengganti ginjal berupa dialisis semakin meningkat, maka diperlukan peningkatan jumlah penyelenggaraan pelayanan dialisis di fasilitas pelayanan kesehatan di Indonesia.

Peningkatan jumlah fasilitas pelayanan kesehatan yang menyelenggarakan pelayanan dialisis harus juga diikuti dengan peningkatan sumber daya manusia baik dari segi jumlah maupun kompetensi dan kewenangannya. Sumber daya manusia yang diperlukan dalam pelayanan hemodialisis terdiri dari dokter spesialis penyakit dalam (konsulen ginjal hipertensi), dokter spesialis penyakit dalam, tenaga kesehatan lainnya (dokter umum dan perawat hemodialisis), teknisi yang memahami tentang mesin hemodialisis, tenaga farmasi yang memahami tentang cairan dialisat dan perlengkapan lainnya yang diperlukan untuk hemodialisis, maupun sumber daya manusia lainnya sesuai dengan kebutuhan.

Dalam hal tenaga kesehatan, tidak semua tenaga kesehatan, dalam hal ini dokter umum dan perawat, dapat/boleh melakukan tindakan hemodialisis. Tindakan hemodialisis seharusnya dilakukan oleh seorang dokter spesialis penyakit dalam (konsulen ginjal hipertensi), dokter spesialis penyakit dalam dan perawat yang telah memiliki sertifikat hemodialisis. Namun pada kenyataannya, di beberapa rumah sakit, tindakan hemodialisis dilakukan oleh dokter umum dan

1 Rully Roesli, dkk. 2011. 3th Report Of Indonesian Renal Registry. Pernefri-Registrasi Ginjal Indonesia. 
perawat baik yang telah bersertifikat pelatihan dialisis maupun yang belum memiliki sertifikat hemodialisis. Hal ini dikarenakan jumlah dan distribusi/penempatan dokter spesialis penyakit dalam (konsulen ginjal hipertensi) yang seharusnya melakukan tindakan hemodialisis belum sesuai dengan meningkatnya jumlah rumah sakit yang menyelenggarakan pelayanan dialisis.

\section{Perumusan Masalah}

Penyakit gagal ginjal kronik termasuk salah satu penyakit yang tindakan penatalaksanaannya memiliki risiko yang cukup besar dengan beberapa komplikasi yang dapat timbul baik karena penyakitnya itu sendiri maupun karena tindakan medis yang dilakukan untuk menindaklanjuti terapi penyakit tersebut yang berupa tindakan hemodialisis ${ }^{2}$.

Adanya kekurangan jumlah dari dokter spesialis penyakit dalam (konsulen ginjal hipertensi), tidak adanya dokter spesialis penyakit dalam yang praktik menetap di suatu rumah sakit, dan kurangnya perawat yang memiliki sertifikat hemodialisis menyebabkan tindakan hemodialisis dilimpahkan kepada dokter umum dan perawat, tidak jarang dokter umum dan perawat tersebut belum memiliki sertifikat hemodialisis.

Secara hukum, tindakan ini tidak dapat memberikan jaminan perlindungan hukum baik bagi pasien yang menjalani hemodialisis, bagi dokter dan perawat yang melakukan tindakan hemodialsis, maupun bagi rumah sakit sebagai penyelenggara pelayanan hemodialisis. Dikatakan tidak dapat memberikan jaminan perlindungan hukum karena tindakan hemodialisis merupakan tindakan yang sangat berisiko dan komplikasi hemodialisis dapat terjadi baik sebelum, saat, maupun setelah dilakukannya hemodialisis.

Oleh karena tindakan dialisis merupakan suatu tindakan yang berisiko serta semakin banyaknya tuntutan-tuntutan hukum terutama bagi fasilitas pelayanan kesehatan dan tenaga kesehatan, maka sumber daya manusia yang terlibat di dalam tindakan dialisis haruslah memiliki kompetensi ${ }^{3}$ sesuai dengan keahliannya, dimana melalui kompetensi yang dimilikinya diharapkan tenaga kesehatan mampu untuk mengerjakan suatu tugas atau pekerjaan, melakukan perencanaan-perencanaan lain apabila terjadi sesuatu yang berbeda dari rencana semula, menggunakan kemampuan yang dimilikinya untuk memecahkan masalah atau melaksanakan tugas dengan kondisi yang berbeda, menyesuaikan kemampuan yang dimiliki apabila harus bekerja dalam kondisi dan lingkungan yang berbeda. Selain kompetensi, tenaga kesehatan juga perlu mendapat kewenangan dari Rumah Sakit (kewenangan klinis atau clinical privilege) bersangkutan untuk melakukan tindakan hemodialisis sehingga diharapkan tindakan yang berisiko ini dapat memberikan perlindungan tidak hanya bagi penderita yang menjalani dialisis, tetapi juga bagi rumah sakit sebagai fasilitas kesehatan yang menyelenggarakan dialisis.

Seorang tenaga kesehatan yang memiliki kompetensi dalam hal pelayanan kesehatan untuk dapat melakukan tindakan hemodialisis diperlukan sertifikat pelatihan hemodialisis yang dikeluarkan oleh kolegium terkait, dalam hal ini Pernefri. Dengan adanya kompetensi yang diperkuat dengan sertifikat pelatihan hemodialisis maka tenaga kesehatan akan memperoleh kewenangan dari Rumah Sakit yang memberikan pelayanan hemodialisis untuk dapat melakukan tindakan hemodialisis, sehingga tenaga kesehatan dan rumah sakit yang memberikan pelayanan dalam bidang hemodialisis akan memiliki kekuatan perlindungan hukum yang lebih pasti.

\footnotetext{
2 Hemodialisis adalah salah satu jenis terapi pengganti ginjal yang dilakukan dengan mengalirkan darah ke dalam suatu tabung ginjal buatan (dializer), dimana dalam proses ini terjadi aliran darah di luar tubuh; Lihat Pudji Rahardjo, Endang Susalit, Suhardjono. 2009. Buku Ajar Ilmu Penyakit Dalam Jilid II : Hemodialisis. Jakarta. Interna Publishing. hlm. 1050.

3 Kompetensi adalah seperangkat tindakan cerdas, penuh tanggung jawab yang dimiliki seseorang sebagai syarat untuk dianggap mampu oleh masyarakat dalam melaksanakan tugas-tugas di bidang pekerjaan tertentu; sesuai dengan Pasal 1 Surat Keputusan Menteri Pendidikan Nasional Nomor 045/U/2002 tentang Kurikulum Inti Pendidikan Tinggi
} 
Selain kompetensi dan kewenangan klinis juga diperlukan suatu regulasi yang mengatur penyelenggaraan dialisis sehingga dengan dikeluarkannya peraturan perundang-undangan tersebut akan memberikan perlindungan hukum baik terhadap dokter yang bekerja di rumah sakit dan/atau klinik sebagai pusat fasilitas pelayanan kesehatan maupun terhadap penderita yang memerlukan penatalaksanaan terhadap penyakitnya tersebut, karena baik tenaga kesehatan maupun penderita merupakan manusia yang memiliki hak untuk mendapatkan jaminan perlindungan hukum.

Penjelasan Pasal 2 Undang-Undang Republik Indonesia Nomor 36 Tahun 2009 tentang Kesehatan disebutkan adanya asas-asas yang dapat memberikan jaminan bagi penerima maupun pemberi pelayanan kesehatan, salah satunya adalah asas perlindungan hukum. Asas perlindungan dalam pasal ini memiliki arti bahwa pembangunan kesehatan harus dapat memberikan perlindungan kepada pemberi dan penerima pelayanan kesehatan melalui kepastian hukum.

Perlindungan bagi tenaga kesehatan telah diatur oleh pemerintah melalui Pasal 24 ayat (1) Peraturan Pemerintah Republik Indonesia Nomor 32 Tahun 1996 tentang Tenaga Kesehatan disebutkan bahwa "Perlindungan hukum diberikan kepada tenaga kesehatan yang melakukan tugasnya sesuai dengan standar profesi tenaga kesehatan." Perlindungan bagi pasien sebagai penerima pelayanan kesehatan tertuang dalam Pasal 2 dan Pasal 3 Undang-Undang Republik Indonesia Nomor 29 Tahun 2004 tentang Praktik Kedokteran dimana secara umum disebutkan bahwa penyelenggaraan pelayanan kesehatan harus dapat memberikan jaminan perlindungan bagi pasien. Sedangkan perlindungan hukum terhadap Rumah Sakit termasuk dalam salah satu hak bagi fasilitas penyelenggaraan kesehatan. Hal ini dinyatakan dalam Pasal 30 ayat (1) huruf (f) Undang-Undang Republik Indonesia Nomor 44 Tahun 2009 tentang Rumah Sakit dimana "Setiap Rumah Sakit mempunyai hak mendapatkan perlindungan hukum dalam melaksanakan pelayanan kesehatan."

Perlindungan hukum terhadap pelayanan dialisis tertuang dalam bentuk peraturan perundang-undangan yaitu Peraturan Menteri Kesehatan Republik Indonesia Nomor 812 Tahun 2010 tentang Penyelenggaraan Pelayanan Dialisis pada Fasilitas Pelayanan Kesehatan. Tanpa adanya peraturan perundang-undangan yang mengatur mengenai pelayanan dialisis pada fasilitas pelayanan kesehatan yang melakukan pelayanan dialisis maka batasan-batasan hukum mengenai dialisis masih belum jelas, sehingga baik penderita maupun fasilitas pelayanan kesehatan dapat dengan mudah terkena tuntutan-tuntutan hukum.

Dengan adanya peraturan perundang-undangan mengenai dialisis diharapkan dapat memberikan perlindungan bagi penderita yang harus menjalankan dialisis dan rumah sakit sebagai fasilitas pelayanan kesehatan.

Berdasarkan latar belakang tersebut, maka penulis tertarik untuk melakukan penelitian dengan judul "Kompetensi Sumber Daya Manusia Dalam Penyelenggaraan Hemodialisis Di Rumah Sakit Dihubungkan Dengan Asas Perlindungan Hukum" (Penelitian Hukum Normatif Terhadap Undang-Undang Nomor 44 Tahun 2009 Tentang Rumah Sakit Dan Permenkes No. 812 Tahun 2010 tentang Penyelenggaraan Pelayanan Dialisis pada Fasilitas Pelayanan Kesehatan)."

Untuk mendapatkan gambaran alur penelitian yang teratur dan terarah, maka identifikasi masalah pada penelitian ini adalah:

1. unsur-unsur apakah yang ada dalam kompetensi sumber daya manusia dalam penyelenggaraan pelayanan hemodialisis?;

2. unsur-unsur apakah yang ada dalam ketentuan tentang penyelenggaraan pelayanan hemodialisis pada rumah sakit?;

3. unsur-unsur apakah yang ada dalam asas perlindungan hukum?; 
4. apakah ketentuan tentang penyelenggaraan pelayanan hemodialisis menyebabkan dipenuhinya asas perlindungan hukum?.

\section{Metode Penelitian}

Berdasarkan gambaran alur penelitian tersebut, maka metode penelitian yang digunakan dalam tesis ini yaitu metode penelitian deskriptif. Metode penelitian ini dilakukan dengan menganalisis penelitian kaidah peraturan perundangan menggunakan data sekunder berupa Peraturan Menteri Kesehatan yang berkaitan dengan asas-asas hukum, dengan pendekatan yang berupa metode yuridis normatif.

Jenis data yang diolah dalam penelitian ini berupa data sekunder, dengan bahan hukum dalam penelitian ini adalah bahan hukum primer yang berupa Permenkes No. 812 Tahun 2010 tentang Penyelenggaraan Pelayanan Dialisis pada Fasilitas Pelayanan Kesehatan. Dari bahan hukum primer ini kemudian dikaitkan dengan peraturan perundang-undangan yang berlaku di Indonesia, dalam hal ini Undang-Undang Republik Indonesia Nomor 44 Tahun 2009 tentang Rumah Sakit.

Teknik pengumpulan data yang dilakukan adalah studi kepustakaan, dimana teknik analisis data sekunder dalam penelitian ini dilakukan secara kualitatif dimana penelitian ini tidak melakukan pengukuran menggunakan angka atau rumusan statistik.

Hasil pengumpulan data yang diperoleh yang berupa data sekunder kemudian dianalisis dan dilakukan pembahasan dalam bentuk kalimat yang dituliskan secara logis dan sistematis. Pembahasan dilakukan dengan mencari hubungan keterkaitan antara kaidah hukum dengan asas hukum terpilih. ${ }^{4}$

\section{HASIL DAN PEMBAHASAN}

Dalam hal ketenagaan (sumber daya manusia) dalam penyelenggaraan pelayanan hemodialisis merupakan komponen yang penting dalam unit hemodialisis karena sumber daya manusia inilah yang mengontrol semua tindakan hemodialisis, mulai dari pemeriksaan awal dan diagnosis gagal ginjal terminal terhadap pasien, yang kemudian berlanjut pada pelaksanaan tindakan hemodialisis, penatalaksanaan terhadap komplikasi-komplikasi yang muncul dalam suatu tindakan hemodialisis, hingga pada penyiapan dan pengoperasian terhadap sarana, prasana, dan peralatan yang berhubungan dengan hemodialisis dalam hal ini mesin hemodialisis, dializer. Karena itulah diperlukan kompetensi dan kewenangan dari sumber daya manusia untuk dapat mempersiapkan dan melakukan hemodialisis sesuai dengan keilmuan dan pengetahuannya masing-masing.

Seorang tenaga kesehatan dalam melakukan praktiknya harus sesuai dengan kompetensi dalam bidang keahliannya masing-masing. Kompetensi ini diperoleh melakui suatu uji kompetensi yang diselenggarakan oleh organisasi profesi masing-masing. Untuk dokter diselenggarakan oleh Konsil Kedokteran Indonesia, untuk perawat diselenggarakan oleh Perhimpunan Perawat Nasional Indonesia, dan untuk teknisi elektromedis kualifikasi teknisi elektromedik ditetapkan oleh organisasi profesi, yaitu Ikatan Ahli Teknik Elektro Medik Indonesia (IKATEMI).

Kompetensi sendiri merupakan suatu kemampuan dan keterampilan yang dimiliki oleh seorang tenaga kesehatan berdasarkan bidang keilmuannya. Kompetensi dapat diperoleh melalui pendidikan formal dan nonformal. Melalui kompetensi inilah maka tenaga kesehatan dianggap mampu dan terampil untuk memberikan pelayanan kesehatan kepada masyarakat.

4 Lihat Moh. Nazir. 2011. Metode Penelitian. Bogor. Penerbit Ghalia Indonesia. hlm. 54-55. 
Sumber daya manusia yang memiliki kompetensi untuk melakukan tindakan hemodialisis berdasarkan Pasal 4 ayat (3) Peraturan Menteri Kesehatan Republik Indonesia Nomor 812 Tahun 2010 tentang Penyelenggaraan Pelayanan Dialisis pada Fasilitas Pelayanan Kesehatan adalah:

1. Dokter spesialis penyakit dalam konsulen ginjal hipertensi, Dalam hal ini, konsulen ginjal hipertensi bertindak sebagai supervisor unit dialisis dengan tugas membina, mengawasi, dan sebagai penanggung jawab atas kualitas pelayanan dialisis dalam unit dialisis bersangkutan.

2. Dokter spesialis penyakit dalam yang terlatih bersertifikat pelatihan hemodialisis,

3. Perawat mahir hemodialisis,

4. Teknisi elektromedis dengan pelatihan khusus mesin dialisis.

Dokter berdasarkan keilmuan dan pengetahuannya harus mampu mendiagnosis penyakit sesuai dengan gejala dan pemeriksaan penunjang. Seorang dokter spesialis penyakit dalam (konsulen ginjal hipertensi) memiliki kompetensi dan kewenangan dalam penatalaksanaan tindakan hemodialisis. Kompetensi dan kewenangan ini diperoleh dari kolegium yang bersangkutan, yaitu PB Pernefri.

Berdasarkan kompetensi dan kewenangan inilah maka seorang dokter spesialis penyakit dalam konsulen ginjal hipertensi bertindak sebagai supervisor (pengawas) dan penanggung jawab suatu tindakan hemodialisis. Selain dokter spesialis penyakit dalam konsulen ginjal hipertensi, seorang dokter spesialis penyakit dalam yang bersertifikat pelatihan hemodialisis memiliki kompetensi dan kewenangan dalam melakukan tindakan hemodialisis, dan juga dapat bertindak sebagai penanggung jawab tindakan hemodialisis apabila dalam rumah sakit bersangkutan tidak terdapat dokter spesialis penyakit dalam konsulen ginjal hipertensi.

Perawat yang berkompeten dalam melakukan hemodialisis adalah perawat minimal lulusan D3 Akademi Keperawatan, yang telah memiliki STR (Surat Tanda Registrasi) melalui uji kompetensi yang diselenggarakan oleh PPNI (persatuan Perawat Nasional Indonesia) dan telah memiliki sertifikat pelatihan hemodialisis yang diselenggarakan oleh Pernefri.

Teknisi elektromedis yang memiliki kompetensi dalam tindakan hemodialisis minimal lulusan STM/D3 Akademi Teknik Elektromedik, dan telah memiliki sertifikat pelatihan hemodialisis. Sertifikat pelatihan hemodialisis dalam hal ini berhubungan dengan penguasaan seorang teknisi elektromedik dalam mengoperasikan dan memelihara mesin hemodialisis yang memiliki beraneka ragam merek namun inti dari fungsi mesin hemodialisis adalah sama yaitu untuk membantu ginjal buatan untuk membuang racun dalam tubuh melalui hemodialisis. Untuk dapat memahami karakter masing-masing merek mesin, maka seorang teknisi elektromedis di Rumah Sakit harus mengikuti pelatihan yang diadakan oleh produsen mesin bersangkutan yang mesinnya digunakan dalam Rumah Sakit tersebut agar teknisi tersebut dapat memahami dan mampu untuk mengoperasikan mesin tersebut.

Namun pada kenyataannya, di Indonesia hemodialisis banyak dilakukan oleh dokter umum dan perawat, itupun yang belum memiliki sertifikat pelatihan dialisis. Hal ini disebabkan oleh karena jumlah dokter spesialis penyakit dalam yang masih kurang. Selain itu dikarenakan penyebaran dokter spesialis penyakit dalam yang masih belum merata di seluruh daerah, sementara unit hemodialisis yang ada banyak juga yang terdapat di daerah-daerah.

Selain ketidaktersediaan dokter spesialis penyakit dalam, banyak Rumah Sakit yang tidak mengirimkan tenaga kesehatannya, dalam hal ini dokter dan perawat, untuk mengikuti pelatihan dialisis.

Masih banyak juga unit hemodialisis yang melaksanakan hemodialisis tanpa adanya tenaga teknisi elektromedis. Hal ini disebabkan jumlah tenaga teknisi elektromedis yang bekerja di unit hemodialisis masih sangat sedikit. Lulusan tenaga elektromedis yang tersedia lebih banyak yang bekerja di unit laboratorium penunjang, seperti unit radiologi. 
Tentunya bagi unit hemodialisis yang melakukan hemodialisis hanya oleh perawat yang belum bersertifikat dialisis adalah salah. Karena mengingat risiko medis yang tinggi dimana di dalam tindakan ini terdapat banyak komplikasi yang dapat terjadi. Apabila sampai terjadi suatu komplikasi yang berat dan terjadi suatu kematian, maka kesalahan mutlak terdapat pada Rumah Sakit yang bersangkutan, dan Rumah Sakit tersebut wajib bertanggung jawab penuh terhadap apa yang telah terjadi dan telah dilakukan oleh tenaga kesehatan yang bersangkutan.

Seorang dokter spesialis penyakit dalam konsulen ginjal hipertensi dan/atau dokter spesialis penyakit dalam bersertifikat pelatihan dialisis berdasarkan Pasal 4 ayat (3) Peraturan Menteri Kesehatan Republik Indonesia Nomor 812 Tahun 2010 tentang Penyelenggaraan Pelayanan Dialisis pada Fasilitas Pelayanan Kesehatan merupakan tenaga kesehatan yang memiliki kompetensi dan kewenangan dalam tindakan hemodialisis maka sudah menjadi suatu kewajiban dan keharusan bagi dokter tersebut untuk melakukan tindakan hemodialisis mulai dari pemeriksaan awal sebelum dilakukannya tindakan hemodialisis sampai tindakan hemodialisis tersebut dilakukan dan tetap melakukan follow up segera setelah tindakan hemodialisis berakhir. Namun dalam praktiknya, banyak dokter spesialis penyakit dalam bersangkutan hanya melakukan pemeriksaan awal saja, dan untuk tindakan hemodialisisnya diserahkan kepada tenaga kesehatan, dalam hal ini perawat dan dokter umum bersertifikat pelatihan hemodialisis, yang bertugas di unit hemodialisis tersebut.

Di dalam Permenkes Nomor 812 Tahun 2010 tentang Penyelenggaraan Pelayanan Dialisis pada Fasilitas Pelayanan Kesehatan tidak disebutkan bahwa dokter umum yang telah bersertifikat pelatihan dialisis sebagai salah satu persyaratan ketenagaan dalam suatu penyelenggaraan pelayanan hemodialisis. Berdasarkan Permenkes Nomor 812 Tahun 2010 tentang Penyelenggaraan Pelayanan Dialisis pada Fasilitas Pelayanan Kesehatan yang memiliki wewenang dalam melakukan terapi pengganti ginjal, dalam hal ini hemodialisis hanya seorang dokter spesialis penyakit dalam dan/atau dokter spesialis penyakit dalam konsulen ginjal hipertensi.

Jumlah dokter spesialis penyakit dalam dan/atau dokter spesialis penyakit dalam konsulen ginjal hipertensi sebagai penanggung jawab dan dokter pelaksana hemodialisis di Indonesia tidak seimbang dengan peningkatan jumlah pasien penderita gagal ginjal kronik yang setiap tahunnya semakin meningkat. Oleh karena permasalahan tersebut maka Pernefri sebagai kolegium yang berhubungan dengan penyakit ginjal di Indonesia mengeluarkan keputusan bahwa dokter umum yang bersertifikat pelatihan dialisis memiliki kompetensi untuk dapat membantu pelayanan kesehatan dalam bidang dialisis (dalam hal ini hemodialisis) sebagai dokter pelaksana harian dalam Unit Hemodialisis.

Kompetensi keterampilan klinis dari seorang dokter umum dalam tindakan terapeutik dialisa ginjal berdasarkan Standar Kompetensi Dokter Indonesia hanya berada dalam tingkat keterampilan 2.

Tingkat keterampilan 2 ini hanya pada tingkatan memahami clinical reasoning dan problem solving. Dengan kata lain, melalui keterampilan klinis ini seorang dokter umum harus memiliki suatu penalaran klinis dalam proses pengambilan keputusan klinis dari suatu permasalahan kesehatan. Setiap tindakan yang dilakukan oleh seorang dokter seperti penentuan diagnosis suatu penyakit, pemilihan terapi yang sesuai, maupun menentukan prognosis suatu penyakit merupakan suatu proses pemahaman dan pemikiran yang logis terhadap suatu permasalahan penyakit. Tindakan anamnesis, pemeriksaan fisik, diagnosis, tindakan terapi, maupun tindakan melakukan rujukan yang dilakukan seorang dokter harus selalu didasari oleh kemampuan melakukan penalaran klinis. Hal ini dikarenakan meskipun setiap pasien memiliki diagnosis yang sama, namun keluhan dan gejala klinik yang dialaminya berbeda-beda. 
Tingkat kemampuan 2 dari Standar Kompetensi Dokter Indonesia ini secara jelas menyatakan bahwa kompetensi dokter umum hanya sebatas pada penetapan diagnosis klinik, dalam hal ini diagnosis gagal ginjal kronik yang telah didukung melalui pemeriksaan fisik dan pemeriksaan pendukung lainnya yang berupa pemeriksaan laboratorium. Dokter umum tidak berhak melakukan tindakan lanjut terhadap penyakit gagal ginjal kronik tersebut yang berupa tindakan hemodialisis. Apabila didapatkan diagnosis klinik gagal ginjal kronik, maka dokter umum wajib menentukan rujukan yang paling tepat bagi penanganan pasien dengan gagal ginjal kronik selanjutnya. Kemudian seorang dokter diharapkan mampu menindaklanjuti sesudah kembali dari rujukan.

Tingkat kemampuan keterampilan klinis 2 seorang dokter umum merupakan kompetensi utama yang harus dimiliki oleh dokter umum dalam praktik kedokteran yang berdasarkan pada ilmu pengetahuan dan keterampilan yang dimilikinya. Kompetensi utama ini diperoleh melalui pendidikan formal di universitas, yang kemudian diakui oleh kolegium kedokteran dengan dikeluarkannya sertifikat kompetensi yang diperoleh melalui suatu uji kompetensi.

Tindakan melakukan hemodialisis berdasarkan Standar Kompetensi Dokter Indonesia yang dikeluarkan oleh Konsil Kedokteran Indonesia bukan merupakan kompetensi seorang dokter umum. Hal ini didukung dengan Pasal 4 ayat (3) Peraturan Menteri Kesehatan Republik Indonesia Nomor 812 Tahun 2010 tentang Penyelenggaraan Pelayanan Dialisis Pada Fasilitas Pelayanan Kesehatan yang menyebutkan bahwa tenaga kesehatan (dalam hal ini dokter) yang memiliki kompetensi dan kewenangan untuk melakukan tindakan hemodialisis adalah dokter spesialis penyakit dalam konsulen ginjal hipertensi dan dokter spesialis penyakit dalam yang telah terlatih bersertifikat pelatihan hemodialisis.

Untuk dapat melakukan tindakan hemodialisis, maka kemampuan keterampilan klinis seorang dokter umum harus ditingkatkan menjadi tingkat kemampuan keterampilan klinis 3 . Tingkat kemampuan keterampilan klinis 3 bagi dokter umum berarti pernah melakukan atau menerapkan suatu tindakan medis khusus dibawah pengawasan seorang supervisi.

Peningkatan kemampuan keterampilan ini diperoleh melalui suatu pelatihan hemodialisis. Pelatihan dialisis adalah pendidikan non formal dimana pendidikan non formal ini merupakan suatu kompetensi pendukung ${ }^{5}$ yang mendukung kompetensi utama dari seorang dokter untuk dapat melaksanakan suatu tindakan medis yang bersifat khusus, dalam hal ini tindakan hemodialisis. Tujuan dari penyelenggaraan pelatihan hemodialisis bagi dokter umum adalah untuk meningkatkan kemampuan, keterampilan, dan pengetahuannya dalam bidang hemodialisis sehingga diharapkan dapat membantu dokter spesialis penyakit dalam konsulen ginjal hipertensi dan/atau dokter spesialis penyakit dalam terlatih bersertifikat dialisis sebagai dokter pelaksana hemodialisis yang kompeten dalam suatu unit hemodialisis yang diakui oleh Pernefri.

Pelatihan untuk meningkatkan kemampuan, keterampilan, dan pengetahuan seorang tenaga kesehatan dalam melakukan suatu tindakan medis didukung oleh Pasal 26 ayat (1) Undang-Undang Republik Indonesia Nomor 20 tahun 2003 tentang Sistem Pendidikan Nasional dan Pasal 9 ayat (1) Peraturan Pemerintah Republik Indonesia Nomor 32 Tahun 1996 tentang Tenaga Kesehatan. Secara tesirat di dalam kedua peraturan perundangan tersebut dikatakan bahwa pendidikan non formal diperlukan sebagai pelengkap untuk dapat meningkatkan kemampuan, keterampilan, dan pengetahuan seorang tenaga kesehatan.

5 Kompetensi pendukung merupakan kompetensi lulusan yang berhubungan dengan program studi yang bersangkutan. Kompetensi pendukung ini tidak wajib diberikan kepada lulusannya (dalam hal ini tenaga kesehatan). Prosentase kompetensi pendukung dalam mempengaruhi keseluruhan kompetensi adalah 20-40\%; lihat Direktorat Pembelajaran dan Kemahasiswaan Kementrian Pendidikan dan Kebudayaan. Kerangka Kualifikasi Nasional Indonesia. 21 Desember 2011. www.dikti.go.id/files/atur/KKNI/Penyusunan-LO-Prodi. Diunduh pada 12 Agustus 2013 
Pelatihan hemodialisis diselenggarakan oleh lembaga pendidikan terkait yang diakui oleh pemerintah dan telah terakreditasi dan disahkan oleh PB Pernefri sebagai kolegium ginjal di Indonesia. Pelatihan hemodialisis dilakukan selama 3 bulan dengan kurikulum yang mengacu pada perkembangan ilmu pengetahuan dan teknologi kedokteran. Pada akhir pelatihan hemodialisis akan diadakan uji kemampuan dan keterampilan yang telah diperoleh selama pelatihan. Setelah melewati tahapan ujian maka dokter umum dinyatakan kompeten untuk melakukan tindakan hemodialisis. Kompetensi ini dinyatakan melalui sertifikat pelatihan hemodialisis.

Melalui proses pelatihan hemodialisis hingga seorang dokter umum memperoleh sertifikat pelatihan hemodialisis maka tingkat kemampuan keterampilan klinis dokter tersebut dapat dikatakan telah meningkat menjadi tingkat kemampuan keterampilan klinis 3, dan dianggap telah berkompeten untuk melakukan tindakan hemodialisis.

Meskipun dokter umum telah berkompeten untuk melakukan tindakan hemodialisis, namun tanggung jawab serta supervisi dari tindakan hemodialisis di Rumah Sakit tetap berada di dokter spesialis penyakit dalam konsulen ginjal hipertensi dan/atau dokter spesialis penyakit dalam terlatih bersertifikat dialisis.

Dengan tidak adanya dokter spesialis penyakit dalam konsulen ginjal hipertensi dan/atau dokter spesialis penyakit dalam bersertifikat dialisis yang menetap dalam suatu Rumah Sakit maka dokter spesialis tersebut dapat memberikan kewenangannya kepada dokter umum bersertifikat pelatihan dialisis untuk melakukan tindakan hemodialisis dan berperan sebagai dokter pelaksana tindakan hemodialisis.

Kewenangan untuk melakukan tindakan hemodialisis yang dilimpahkan dari dokter spesialis penyakit dalam konsulen ginjal hipertensi dan/atau dokter spesialis penyakit dalam terlatih bersertifikat pelatihan dialisis kepada dokter umum terlatih bersertifikat pelatihan dialisis berupa suatu mandat ${ }^{6}$.

Melalui mandat inilah maka seorang dokter umum terlatih bersertifikat dialisis dapat secara legal melakukan tindakan hemodialisis sesuai dengan instruksi/petunjuk/arahan, dalam hal ini peresepan program hemodialisis dan tindakan-tindakan lain yang diperlukan dlam penatalaksanaan hemodialisis termasuk penatalaksanaan saat terjadi komplikasi-komplikasi, yang diberikan oleh dokter spesialis penyakit dalam konsulen ginjal hipertensi dan/atau dokter spesialis penyakit dalam terlatih hemodialisis.

Kewenangan yang diberikan kepada dokter umum terlatih bersertifikat dialisis berupa mandat karena berdasarkan Pasal 4 ayat (3) Peraturan Menteri Kesehatan Republik Indonesia Nomor 812 Tahun 2010 tentang Penyelenggaraan Pelayanan Dialisis Pada Fasilitas Pelayanan Kesehatan, dokter spesialis penyakit dalam konsulen ginjal hipertensi tetap bertindak sebagai supervisor dan penanggung jawab, dan dokter spesialis penyakit dalam terlatih bersertifikat dialisis sebagai penanggung jawab unit hemodialisis apabila di Rumah Sakit tersebut tidak terdapat dokter spesialis penyakit dalam konsulen ginjal hipertensi yang menetap namun dokter spesialis penyakit dalam konsulen ginjal hipertensi tetap sebagai supervisor unit hemodialisis dalam Rumah Sakit yang bersangkutan.

\footnotetext{
6 Mandat adalah pemberian wewenang oleh organ pemerintahan kepada organ lainnya untuk mengambil keputusan atas namanya. Pemberi mandat tetap berwenang untuk melakukan sendiri wewenangnya apabila ia menginginkannya (tetap berwenang untuk menangani sendiri wewenang bila mana ia menghendaki), dan memberi petunjuk kepada mandataris tentang apa yang diinginkannya. Mandans atau pemberi mandat tetap bertanggung jawab atas tindakan yang dilakukan oleh mandataris; lihat Ridwan HR. 2011. Hukum Administrasi Negara. Jakarta. PT Rajagrafindo Persada. hlm. 104-108.
} 
Persyaratan kompetensi ini juga berlaku untuk perawat yang bekerja di unit hemodialisis Rumah Sakit. Perawat yang bekerja di unit hemodialisis adalah perawat yang telah mengikuti pelatihan hemodialisis dan telah dinyatakan kompeten melalui sertifikat pelatihan dialisis.

Apabila melihat dari Standar Kompetensi Perawat Indonesia yang diterbitkan oleh PPNI (dimana standar ini masih belum diperbarui lagi) maka yang berhak untuk melakukan tindakan hemodialisis adalah perawat vokasional dan perawat profesional, dimana pelaksanaan pelayanan kesehatan yang dilakukan oleh perawat vokasional berada di bawah supervisi dari perawat profesional. Pelaksanaan pelayanan kesehatan yang dilakukan oleh perawat sesuai dengan arahan yang diberikan oleh dokter.

Perawat yang telah memiliki sertifikat pelatihan dialisis termasuk di dalam sumber daya manusia yang berkompetensi untuk memberikan pelayanan kesehatan di unit hemodialisis sesuai dengan Pasal 4 ayat (3) Peraturan Menteri Kesehatan Republik Indonesia Nomor 812 Tahun 2010 tentang Penyelenggaraan Pelayanan Dialisis Pada Fasilitas Pelayanan Kesehatan. Namun di dalam pasal ini, disebutkan istilah perawat mahir. Sementara berdasarkan Standar Kompetensi Perawat Indonesia tidak ada jenis perawat mahir. Hal inilah yang menjadi rancu dimana belum secara jelas ditetapkan dalam Peraturan Menteri Kesehatan Republik Indonesia Nomor 812 Tahun 2010 tentang Penyelenggaraan Pelayanan Dialisis Pada Fasilitas Pelayanan Kesehatan mengenai jenis perawat yang boleh melakukan tindakan hemodialisis.

Pernefri sebagai kolegium ginjal di Indonesia juga tidak menetapkan jenis perawat yang dapat melakukan tindakan hemodialisis. Hal yang paling penting adalah bahwa perawat yang melakukan tindakan hemodialisis haruslah perawat yang telah mengikuti pelatihan hemodialisis dan dinyatakan kompeten melalui sertifikat pelatihan hemodialisis. Melalui pelatihan dialisis, perawat diharapkan dapat melaksanakan tindakan hemodialisis sesuai dengan arahan dokter pelaksana hemodialsis dan/atau dokter penanggung jawab dan/atau dokter supervisor dari unit hemodialisis.

Selain dapat melaksanakan tindakan hemodialisis, perawat juga diharapkan dapat memberikan asuhan keperawatan terhadap pasien gagal ginjal sesuai dengan Standar Kompetensi Perawat Indonesia dan mengoperasikan alat-alat yang berhubungan dengan tindakan hemodialisis.

Dengan dinyatakannya perawat bersertifikat pelatihan dialisis sebagai tenaga kesehatan yang kompeten dalam pelaksanaan tindakan hemodialisis maka perawat telah mendapatkan perlindungan hukum melalui Peraturan Menteri Kesehatan Republik Indonesia Nomor 812 Tahun 2010 tentang Penyelenggaraan Pelayanan Dialisis Pada Fasilitas Pelayanan Kesehatan.

Selain dokter dan perawat, teknisi elektromedik juga berperan dalam penyelenggaraan pelayanan hemodialisis. Teknisi elektromedik yang dipelukan dalam suatu unit hemodialisis adalah teknisi elektromedis dengan pendidikan teknisi elektromedik jalur vokasional ${ }^{7}$. Hal ini dikarenakan jalur pendidikan vokasional mendidik lulusannya untuk siap memasuki dunia kerja.

Kompetensi bagi teknisi elektromedik yang bekerja di unit hemodialisis didapatkan melalui pelatihan hemodialisis, dan memiliki peran sebagai teknisi elektromedik pelaksana ${ }^{8}$. Teknisi elektromedik pelaksana diharapkan mampu mengoperasikan mesin-mesin hemodialisis, memelihara mesin hemodialsis, menguji/melakukan kalibrasi terhadap mesin-mesin hemodialisis dan mesin pendukung pelayanan hemodialisis.

7 Pendidikan vokasi ini memiliki nilai dasar yang khas, yakni adanya hubungan antara perolehan pengetahuan, keterampilan dan sikap dengan nilai kekaryaan (jabatan) khususnya terkait dengan keahlian yang dibutuhkan oleh dunia kerja; lihat Wowo Sunaryo Kuswana. 2013. Filsafat : Pendidikan Teknologi, Vokasi dan Kejuruan. Bandung. Penerbit Alfabeta. hlm. 157.

8 Lihat Keputusan Menteri Kesehatan Republik Indonesia Nomor 371/MENKES/SK/III/2007 tentang Standar Profesi Teknisi Elektromedis 
Seperti telah diketahui bahwa tindakan hemodialisis memiliki banyak risiko, dimana risiko ini juga dapat disebabkan karena peralatan pendukung tindakan hemodialisis. Oleh karena itu, maka diperlukan teknisi elektromedik yang berkompeten dalam bidang hemodialisis sehingga diharapkan dapat memberikan perlindungan bagi pasien sebagai penerima pelayanan hemodialsis.

Mesin hemodialisis memiliki bermacam-macam merek namun pada prinsipnya semua merek ini adalah sama. Oleh karena itu dari kompetensi yang telah diperoleh teknisi elektromedis melalui pelatihan dialisis, diperkuat lagi dengan pelatihan yang diberikan secara khusus oleh distributor dan/atau produsen mesin hemodialisis yang dipergunakan di Rumah Sakit tempat teknisi tersebut bekerja, dimana pelatihan khusus ini dapat dikategorikan dalam kompetensi lainnya yang bersifat gayut dan khusus.

Dengan kompetensi yang dimiliki teknisi elektromedis, diharapkan dapat memberikan perlindungan terhadap teknisi itu sendiri dalam melaksanakan tindakan hemodialisis yang berkaitan dengan alat-alat kesehatan pendukung hemodialisis serta memberikan perlindungan bagi pasien.

Selain kompetensi yang harus dimiliki sesuai dengan bidangnya masing-masing dan sertifikat pelatihan dialisis yang telah dimiliki, sumber daya manusia yang melaksanakan tindakan hemodialisis juga memerlukan kewenangan untuk dapat melakukan praktik medis yang diberikan oleh Rumah Sakit kepada sumber daya manusia yang bersangkutan sesuai dengan bidang kerjanya. Kewenangan untuk melakukan praktik medis di dala Rumah Sakit diberikan dalam bentuk kewenangan klinis (clinical privillege) ${ }^{9}$. Rumah Sakit harus memberikan suatu kewenangan klinis kepada sumber daya manusia yang terkait dengan tindakan hemodialisis yang dilakukan oleh sumber daya manusia sesuai dengan kompetensi bidangnya masing-masing. Kewenangan klinis yang diberikan oleh Rumah Sakit merupakan acuan bagi dokter, perawat, dan teknisi elektromedis sebagai sumber daya manusia dalam melaksanakan tugasnya di hemodialisis.

Kewenangan klinis ini diberikan kepada tenaga kesehatan melalui penugasan klinis sehingga sumber daya manusia dapat melakukan tindakan hemodialisis sesuai dengan kompetensinya.

Seperti yang telah dibahas sebelumnya pada pembahasan Pasal 4, telah disebutkan bahwa tenaga kesehatan yaitu dokter spesialis penyakit dalam konsulen ginjal hipertensi dan/atau dokter spesialis penyakit dalam terlatih dialisis dapat memberikan kewenangan berupa mandat kepada dokter umum bersertifikat pelatihan dialisis sebagai dokter pelaksana dalam tindakan hemodialisis. Pemberian kewenangan untuk melakukan hemodialisis hanya dapat diberikan kepada dokter umum yang telah mengikuti pelatihan hemodialisis yang diselenggarakan oleh organisasi profesi yang bersangkutan, dalam hal ini Pernefri dan telah dinyatakan memiliki kompetensi pendukung, dalam hal ini telah memiliki sertifikat pelatihan dialisis. Selain memiliki sertifikat pelatihan dialisis, dokter umum ini juga memiliki izin praktik di unit hemodialisis Rumah Sakit tempat dokter tersebut bekerja dan memperoleh kewenangan klinis dari Rumah Sakit bersangkutan.

Adanya sertifikat pelatihan dialisis dan surat izin praktik tidak hanya berlaku bagi dokter, tetapi juga berlaku bagi perawat dan sertifikat pelatihan dialisis bagi teknisi elektromedis yang bekerja di unit hemodialisis Rumah Sakit.

\footnotetext{
9 Kewenangan klinis (clinical privilege) adalah hak khusus seorang staf medis untuk melakukan sekelompok pelayanan medis tertentu dalam lingkungan rumah sakit untuk suatu periode tertentu yang dilaksanakan berdasarkan penugasan klinis (clinical appointment); lihat Pasal 1 angka (7) Peraturan Menteri Kesehatan Republik Indonesia Nomor 755/MENKES/PER/IV/2011 tentang Penyelenggaraan Komite Medik Di Rumah Sakit.
} 
Selain persyaratan kompetensi dan kewenangan tersebut, dalam melakukan pelayanan kesehatan kepada pasien, tenaga kesehatan dan tenaga non kesehatan juga harus bertindak sesuai dengan standar profesi masing-masing sumber daya manusia serta standar operasional prosedur yang telah ditetapkan oleh Rumah Sakit bersangkutan.

Dengan adanya pelayanan kesehatan yang sesuai dengan standar profesi masing-masing bidang sumber daya manusia yang bersangkutan dan standar operasional prosedur pelayanan kesehatan dari Rumah Sakit bersangkutan, yang didukung dengan adanya surat izin praktik dan sertifikat pelatihan dialisis serta kewenangan yang diberikan baik oleh Rumah Sakit bersangkutan maupun oleh dokter spesialis penyakit dalam terlatih dialisis maka hal ini akan memberikan jaminan perlindungan baik bagi tenaga kesehatan dan tenaga non kesehatan bersangkutan yang bekerja di unit hemodialisis maupun bagi Rumah Sakit sebagai penanggung jawab pelayanan kesehatan. Selain itu juga memberikan jaminan perlindungan dan keselamatan bagi pasien sebagai penerima pelayanan kesehatan.

\section{PENUTUP}

\section{Kesimpulan}

Dari penelitian yang penulis lakukan terhadap Peraturan Menteri Kesehatan Republik Indonesia Nomor 812 Tahun 2010 tentang Penyelenggaraan Pelayanan Dialisis pada Fasilitas Pelayanan Kesehatan maka dapat disimpulkan bahwa:

1. Unsur-unsur yang terdapat dalam kompetensi sumber daya manusia dalam penyelenggaraan hemodialisis adalah lulus dalam uji kompetensi berdasarkan keilmuan dan keahliannya yang mengacu terhadap standar profesi yang dibuat oleh masing-masing organisasi profesi, memiliki sertifikat pelatihan dialisis yang diselenggarakan oleh kolegium Pernefri.

2. Unsur-unsur yang ada dalam ketentuan penyelenggaraan pelayanan dialisis pada Rumah Sakit adalah adanya sarana, prasarana, dan peralatan yang mendukung tindakan hemodialisis, sumber daya manusia yang terdiri dari tenaga kesehatan, yaitu dokter spesialis penyakit dalam konsulen ginjal hipertensi sebagai supervisor dan/atau penanggung jawab unit hemodialisis di Rumah Sakit, dokter spesialis penyakit dalam terlatih bersertifikat dialisis sebagai penanggung jawab unit hemodialisis di Rumah Sakit, dokter umum terlatih bersertifikat pelatihan dialisis yang berfungsi sebagai dokter pelaksana harian tindakan hemodialisis, perawat vokasional dan perawat profesional terlatih bersertifikat hemodialisis, teknisi elektromedis yang bersertifikat pelatihan dialisis dan telah mengikuti pelatihan mesin hemodialisis dan mesin-mesin pendukung tindakan hemodialisis.

3. Unsur-unsur yang terdapat dalam asas perlindungan hukum adalah penyelenggaraan pelayanan kesehatan yang sesuai dengan kompetensi tenaga kesehatan sesuai dengan bidangnya masing-masing, kewenangan dan kewenangan klinis (clinical privilege) yang dimiliki tenaga kesehatan yang diperoleh dari Rumah Sakit bersangkutan, standar profesi sumber daya manusia (dokter, perawat, dan teknisi elektromedis), standar operasional prosedur yang berlaku di rumah sakit, hak-hak dari pasien, hak-hak dari rumah sakit.

4. Ketentuan tentang penyelenggaraan pelayanan dialisis berdasarkan Peraturan Menteri Kesehatan Republik Indonesia Nomor 812 Tahun 2010 tentang Penyelenggaraan Pelayanan Dialisis pada Fasilitas Pelayanan Kesehatan telah dapat memenuhi asas perlindungan hukum.

\section{Saran}

Berdasarkan penelitian yang telah penulis susun, maka untuk melihat perkembangan pelayanan dialisis pada fasilitas pelayanan kesehatan pada masa yang akan datang penulis memberikan saran yaitu Peraturan Menteri Kesehatan Republik Indonesia Nomor 812 Tahun 2010 tentang Penyelenggaraan Pelayanan Dialisis pada Fasilitas Pelayanan Kesehatan perlu dikaji ulang 
dimana dalam pengkajian ulang Permenkes ini diperlukan pencantuman lebih jelas lagi/dipertegas lagi mengenai :

1. Fasilitas pelayanan kesehatan yang boleh menyelenggarakan pelayanan dialisis adalah Rumah Sakit dan Klinik Dialisis, mengingat tindakan hemodialisis merupakan tindakan yang dapat dilakukan pada PPK Tingkat Lanjutan.

2. Syarat ketenagaan dalam pelayanan hemodialisis, dimana tenaga kesehatan yang boleh melakukan dapat ditambahkan dokter umum terlatih bersertifikat hemodialisis sebagai dokter pelaksana tindakan hemodialisis sesuai dengan kewenangan klinis yang diperoleh dari rumah sakit yang bersangkutan.

3. Untuk istilah perawat mahir yang tersebut dalam Pasal 4 ayat (3) Peraturan Menteri Kesehatan Republik Indonesia Nomor 812 Tahun 2010 tentang Penyelenggaraan Pelayanan Dialisis pada Fasilitas Pelayanan Kesehatan harus lebih diperjelas karena berdasarkan Standar Kompetensi Perawat Indonesia jenis dan jenjang perawat mahir tidak ada, dan yang berkompetensi untuk melakukan tindakan keperawatan (dalam hal ini tindakan hemodialisis) adalah perawat vokasional dan perawat profesional.

\section{DAFTAR PUSTAKA}

Konsil Kedokteran Indonesia. 2012. Standar Kompetensi Dokter. Jakarta. Penerbit Konsil Kedokteran Indonesia.

Moh. Nazir. 2011. Metode Penelitian. Bogor. Penerbit Ghalia Indonesia.

Persatuan Perawat Nasional Indonesia (PPNI). 2005. Standar Kompetensi Perawat Indonesia Tahun 2005. Jakarta. Penerbit PP-PPNI. Dipublikasikan oleh Bidang Organisasi PP-PPNI.

Pudji Rahardjo, Endang Susalit, Suhardjono. 2009. Buku Ajar Ilmu Penyakit Dalam Jilid II : Hemodialisis. Jakarta. Interna Publishing.

Ridwan HR. 2011. Hukum Administrasi Negara. Jakarta. PT Rajagrafindo Persada.

Rully Roesli, dkk. 2011. $3^{\text {th }}$ Report Of Indonesian Renal Registry. Pernefri-Registrasi Ginjal Indonesia.

Wowo Sunaryo Kuswana. 2013. Filsafat : Pendidikan Teknologi, Vokasi dan Kejuruan. Bandung. Penerbit Alfabeta.

\section{Daftar Peraturan Perundang-undangan}

Keputusan Menteri Kesehatan Republik Indonesia Nomor 371/MENKES/SK/III/2007 tentang Standar Profesi Teknisi Elektromedis

Peraturan Pemerintah Republik Indonesia Nomor 32 Tahun 1996 tentang Tenaga Kesehatan

Pasal 1 angka (7) Peraturan Menteri Kesehatan Republik Indonesia Nomor 755/MENKES/PER/IV/2011 tentang Penyelenggaraan Komite Medik Di Rumah Sakit

Peraturan Menteri Kesehatan Republik Indonesia Nomor 812 Tahun 2010 tentang Penyelenggaraan Pelayanan Dialisis pada Fasilitas Pelayanan Kesehatan

Surat Keputusan Menteri Pendidikan Nasional Nomor 045/U/2002 tentang Kurikulum Inti Pendidikan Tinggi

Undang-Undang Republik Indonesia Nomor 20 tahun 2003 tentang Sistem Pendidikan Nasional Undang-Undang Republik Indonesia Nomor 29 Tahun 2004 tentang Praktik Kedokteran Undang-Undang Republik Indonesia Nomor 36 Tahun 2009 tentang Kesehatan Undang-Undang Republik Indonesia Nomor 44 Tahun 2009 tentang Rumah Sakit

Direktorat Pembelajaran dan Kemahasiswaan Kementrian Pendidikan dan Kebudayaan. Kerangka Kualifikasi Nasional Indonesia. 21 Desember 2011. www.dikti.go.id/files/atur/KKNI/Penyusunan-LOProdi. Diunduh pada 12 Agustus 2013 